\title{
PERILAKU AKTIVITAS OLAHRAGA \\ PADA SAAT BULAN RAMADHAN
}

\author{
Isti Dwi Puspitawati \\ Prodi Pendidikan Kepelatihan Olahraga FKIP Universitas Tanjungpura \\ Email: isti.dwi.puspita.w@fkip.untan.ac.id
}

\begin{abstract}
ABSTRAK
Penelitian ini bertujuan untuk mengetahui perilaku mahasiswa prodi Pendidikan Kepelatihan Olahraga (PKO) selama masa bulan Ramadhan. Sampel penelitian adalah mahasiswa prodi PKO angkatan 2015. Hasil penelitian menunjukkan bahwa dari beberapa mahasiswa angkatan 2015 rata-rata tidak melakukan aktivitas olahraga selama bulan Ramadhan. Hanya terdapat 3 mahasiswa yang tetap melakukan latihan rutin, latihan dilakukan pada waktu malam hari sebagai pengganti dari latihan yang sedianya dilakukan padda sore hari. Hal itu terjadi karena ketiga mahasiswa tersebut masuk dalam tim atlet dalam pekan olahraga mahasiswa yang diselenggarakan di Makasar. Berdasarkan hasil penelitian dapat disimpulkan bahwa rata-rata mahasiswa prodi PKo tidak memindahkan jam latihan karena dampak bulan Ramadhan akan tetapi justru menghilangkan aktivitas olahraga yang sudah secara rutin dilaksanakan setiap hari.
\end{abstract}

Kata Kunci: aktivitas olahraga, Ramadhan 


\section{Jurnal Ilmu Keolahragaan Volume II Nomor 2 Oktober 2019 \\ Isti Dwi Puspitawati \\ Tersedia di: http://jurnal.untan.ac.id/index.php/jilo}

\section{PENDAHULUAN}

Indonesia merupakan Negara yang berbhineka. Kebhinekaan tersebut muncul karena efek dari banyaknya pulau yang ada. Setidaknya terdapat 7 pulau besar yang terhimpun pada Negara Indonesia. Dari berbagai pulau tersebut muncullah budaya yang beragam, termasuk juga keyakinan yang dianut oleh penduduknya. Negara Indonesia mengakui 5 agama yang dianut oleh warga negaranya, yaitu agama Islam, Kristen Katolik, Kristen Protestan, Hindu dan Budha. Dari kelima agama tersebut tentunya memiliki karakteristik yang berbeda-beda. Agama Islam merupakan salah satu agama yang memiliki penganut paling banyak di Indonesia. Fenomena yang selalu dinanti oleh penganut agama ini adalah bulan Ramadhan.

Bulan Ramadhan merupakan bulan yang sangat dinanti oleh mayoritas masyrakat Muslim di Indonesia. Terdapat beberapa kegiatan yang hanya bisa dilakukan pada saat bulan Ramadhan tiba. Contohnya seperti ngabuburit, bertakbir keliling, dan juga berbelanja untuk mempersiapkan berbagai kebutuhan di hari raya Idul Fitri. Pada bulan ini umat Islam tak makan dan minum seharian, tetapi ajaibnya konsumsi makanan meningkat signifikan (Indonesia Consumers, 2004; Zainal A Hidayat, Kompas, 3/10/2006) Bulan Ramadhan memiliki pengaruh terhadap perilaku masyarakat, hal ini dapat dilihat dari perilaku konsumsi masyarakat. Perubahan perilaku konsumsi pada bulan Ramadhan ini ternyata justru menaikkan tingkat konsumsi masyarakat. Peningkatan seperti ini merupakan suatu momen konsumtif yang bersifat musiman.

Penelitian yang dilakukan oleh Erlangga (2014) perubahan perilaku pada bulan Ramadhan bukan hanya terjadi pada perubahan perilaku terhadap konsumsi makanan saja, akan tetapi juga terhadap perilaku konsumsi pada produk kecantikan, pakaian muslim, umum dan olahraga (dalam hal ini lebih banyak penjualan sepatu olahraga).

Umat muslim yang berpuasa akan tidak hanya melakukan perubahan pola makan tetapi juga perubahan pola aktivitas. Perubahan-perubahan itu diantaranya adalah perubahan jam makan, pembatasan waktu makan, dan perubahan pola tidur, hal-hal itu tentunya akan mengubah ritme keseharian seseorang secara drastis dan dapat memberi efek negatif terhadap performa fisik seseorang. Ketika berpuasa, tanpa disadari kinerja tubuh perlahan berubah dan menyesuaikan diri. Saat berpuasa tubuh memproduksi energi sendiri dengan membakar nutrisi yang tersimpan dalam tubuh, seperti cadangan lemak, karbohidrat, dan gula untuk memproduksi energi. Tak hanya itu, organ-organ lain dalam tubuh pun menyesuaikan kinerja mereka dengan keadaan orang yang berpuasa.

Pengurangan jam untuk beraktivitas pun selalu dilakukan pada saat bulan suci Ramadhan ini. Jam disekolah dan kantor selalu dipangkas, satu jam mata pelajaran yang biasanya 50 menit pada bulan Ramadhan menjadi 30 menit. Hal ini disebabkan agar pemeluk dapat melakukan ibadah secara maksimal. Namun apa yang kerap dilakukan adalah lebih banyak dilakukan untuk tidur siang. Dengan lebih banyak beristirahat dalam hal ini tidur maka pastinya akan terjadi penurunan performa fisik.

Penurunan performa fisik saat berpuasa umumnya dikaitkan dengan dehidrasi, keterbatasan asupan nutrisi, kurangnya istirahat, perubahan mood, dan perasaan lemas. Dengan adanya penurunan performa fisik tersebut maka diperlukan keseimbangan. Keseimbangan tersebut meliputi kebutuhan jasmani dan rohani. Dimana olahraga diperlukan untuk memperkuat badan, dan kebersihan rohani untuk mengontrol sekaligus mengarahkan jasmani untuk melakukan aktivitas yang baik juga benar. Jika berat salah satunya dikhawatirkan keseimbangan terganggu. 


\section{Jurnal Ilmu Keolahragaan Volume II Nomor 2 Oktober 2019 Isti Dwi Puspitawati Tersedia di: http://jurnal.untan.ac.id/index.php/jilo}

Ketidakseimbangan tubuh akan berdampak negative. Dampak negative tersebut salah satunya adalah terganggunya system metabolisme tubuh. Ketika system metabolism tubuh berjalan lambat maka akan terjadi penambahan berat badan. Maka tidak heran ketika bulan Ramadhan selesai maka umat muslim cenderung mengalami kenaikan berat badan. Kenaikan berat badan yang drastis akan berdampak negatif terhadap tingkat kesehatan pelakunya. Banyak penyakit yang akan menghampiri ketika kegemukan dan bahkan obesitas melanda. Selain itu tingkat kebugaran jasmani juga akan menurun ketika selama bulan Ramadhan tidak melakukan olahraga.

Berdasarkan masalah tersebut maka peneliti ingin meneliti perilaku aktivitas olahraga selama bulan suci Ramadhan. Adapun rumusan masalah yang diangkat dalam penelitian ini adalah bagaimanakah perilaku aktivitas olahraga mahasiswa program studi pendidikan kepelatihan olahraga angkatan 2015 selama bulan suci Ramadhan?

Melalui penelitian ini diharapkan mampu membuka pengetahuan para mahasiswa khususnya dan masyarakat pada umumnya agar pada saat bulan suci Ramadhan tidak meninggalkan aktivitas olahraga yang sangat penting dilakukan untuk memperoleh performa fisik yang bagus terlebih bagi mahasiswa prodi Pendidikan Kepelatihan Olahraga sebagian besar merupakan atlet.

Anggapan bahwa pada saat puasa Ramadhan akan terjadi beberapa penurunan dalam komponen umum kebugaran (kecepatan, kelincahan, dan daya tahan) dan uji keterampilan individual (seperti dribel) pada saat berpuasa sudah beredar di masyarakat sehingga pada saat puasa tidak dilakukan latihan seperti biasanya. Namun, salah satu penelitian berjudul "The influence of Ramadan on physical performance measures in young Muslim footballers" (Kirkendall dkk, 2012) menunjukkan bahwa tidak ada dampak yang jelas dalam kecepatan, kekuatan, kelincahan, daya tahan, dan keterampilan individual pada saat puasa Ramadhan.

Selama puasa Ramadan, periodisasi yang tepat dari pelatihan ini penting untuk menjaga dan mengoptimalkan kinerja atlet. Penyesuaian pelatihan dapat memiliki dampak luar biasa pada kinerja. Sedangkan bagi yang bukan atlet, jangan terlalu khawatir jika berpuasa akan menghambat kinerja kita, baik dalam bekerja maupun berolahraga. Asalkan kita melahap sahur, berbuka puasa, dan memiliki jam tidur yang teratur, maka puasa tidak akan menimbulkan dampak negatif jika kita ingin tetap terus berolahraga.

Kenyataannya, tubuh tetap membutuhkan latihan fisik agar tetap sehat dan fit. Olahraga adalah cara agar membuat tubuh lebih segar, tidak terasa lemas, dan juga membakar tumpukan lemak. Penyiasatan olahraga selama Ramadan umumnya banyak membahas tentang intensitas dan juga waktu yang tepat untuk berolahraga. Sementara tuntutan nutrisi juga otomatis muncul. Satu hal yang paling penting yang harus selalu diingat adalah, harus senantiasa menyesuaikan olahraga yang akan dilakukan dengan kondisi tubuh yang sedang berpuasa. Penurunan metabolisme tubuh adalah proses yang alami terjadi saat berpuasa. Ini terjadi karena asupan energi (nutrisi dari makanan dan minuman) yang terbatas. Secara umum, jenis latihan atau olahraga tingkat rendah sampai sedang adalah yang paling direkomendasikan untuk mengatasi hal di atas.

Penyiasatan olahraga ketika puasa perlu dilakukan, pada umumnya olahraga dilakukan pada waktu sore hari menjelang berbuka puasa dan setelah berbuka puasa. Olahraga sesaat sebelum berbuka puasa sangat terkenal di Indonesia sebagai "ngabuburit". Beberapa jurnal memang banyak yang menyarankan agar olahraga dilakukan pada waktu ini, yaitu beberapa saat menjelang berbuka. Ngabuburit 


\section{Jurnal Ilmu Keolahragaan Volume II Nomor 2 Oktober 2019 \\ Isti Dwi Puspitawati \\ Tersedia di: http://jurnal.untan.ac.id/index.php/jilo}

menjadi waktu yang umumnya dikategorikan "terbaik" karena sisa energi dan cairan tubuh di sore hari yang habis akan dapat langsung dikembalikan dengan makan dan minum saat buka puasa. Disarankan untuk olahraga sore selama 45-90 menit yang bisa kita mulai dari dua jam sebelum berbuka. Olahraga permainan sangat marak dilakukan saat ngabuburit, seperti futsal, sepakbola, bulu tangkis, voli, dan lain sebagainya. Hal ini sejalan dengan penelitian yang dilakukan oleh Kirkendall dkk (2012) dan Maughan dkk (2012). Penelitian yang dilakukan oleh Alkandari dkk (2012) mengatakan bahwa olahraga pada saat puasa Ramadhan merupakan aktivitas yang aman bagi semua orang, namun bagi orang yang mengalami berbagai penyakit harus melakukan konsultasi dengan dokter dan harus mengikuti rekomendasi medis.

Pada saat puasa semua akan melakukan pembatasan makan dan minum. Selama seharian penuh tanpa makan dan minum. Puasa yang berarti ada pembatasan pada makan dan minum serta jam tidur, akan berkaitan langsung dengan asupan energi dan pemanfaatannya untuk keseharian. Di sinilah peran penting nutrisi agar tubuh dapat berfungsi dengan sebaik-baiknya selama berpuasa.

Nutrisi juga berperan dalam mempertahankan pola latihan atau olahraga selama Bulan Ramadan. Inilah kenapa orang yang berpuasa dan tetap melaksanakan olahraga harus senantiasa memilih jenis makanan dan minuman yang disantap. Pertimbangan utama tentunya tubuh membutuhkan air, karbohidrat, mineral, protein, vitamin, dan juga lemak. Minum air putih atau air mineral dalam jumlah yang banyak merupakan saran yang paling banyak muncul dalam berbagai jurnal. Disarankan untuk minum satu gelas air setiap jamnya, ditambah sekitar 500 mililiter air sebelum tidur, dan jumlah yang sama kembali ketika bangun sebelum sahur.

\begin{abstract}
Penelitian yang dilakukan oleh Maughan dan Shirreffs (2012) mengatakan bahwa kekurangan cairan tubuh yang besar akan mengganggu
\end{abstract} kinerja fisik dan kognitif. Puasa akan mengakibatkan kehilangan air mencapai sekitar $1 \%$ massa tubuh pada saat matahari terbenam tidak akan memiliki efek samping yang merugikan pada aspek kinerja fisik atau kognitif. Namun ketika puasa dan melakukan olahraga maka akan mengakibatkan kehilangan cairan lebih dari $1 \%$ sehingga akan mengganggu penampilan.

Saat puasa, penentuan intensitas dalam berolahraga sangat penting. Menurut Djoko P.I intensitas adalah kualitas yang menunjukkan beratringannya latihan. Olahraga di bulan ramadhan dapat dilakukan dengan intensitas $40 \%$ hingga $50 \%$ lebih sedikit dari zona latihan yang biasa dilakukan. Contoh: apabila biasa lari lima kali seminggu selama satu jam, maka saat puasa cukup lakukan jalan cepat tiga kali seminggu, masing-masing 30 menit. Setiap berolahraga di bulan ramadhan juga jangan lupa melakukan pemanasan dan pendinginan. Lakukan gerakangerakan peregangan (stretching), dengan tujuan dapat terhindar dari cedera atau nyeri otot setelah melakukan olahraga.

Untuk olahraga lain, bisa menggunakan sepeda, spinning atau jalan pakai treadmil. Olahraga seperti jalan sehat atau jalan cepat juga bisa menjadi pilihan. Olahraga kardio justru dianjurkan sebelum berbuka puasa. Latihan pembakaran yang berfungsi untuk kardiovaskular tersebut bermanfaat saat perut kosong. Satu atau setengah jam sebelum berbuka, latihan kardio bisa membakar lemak untuk dipergunakan sebagai energi. Olahraga berpengaruh terhadap penurunan berat badan yaitu dengan melakukan olahraga dapat menurunkan berat badan 2,35 kg sedangkan yang tidak melakukan olahraga penurunan berat badannya hanya $0,66 \mathrm{~kg}$ selama puasa ramadhan. Menurut 


\section{Jurnal Ilmu Keolahragaan Volume II Nomor 2 Oktober 2019 \\ Isti Dwi Puspitawati \\ Tersedia di: http://jurnal.untan.ac.id/index.php/jilo}

personal trainer profesional Jefry Sihite, latihan seperti, yoga, pilates, body balance, lebih tepat dilakukan saat berpuasa. Selain intensitas rendah, latihan tersebut juga memiliki manfaat bagi pikiran dan jiwa.

\section{METODE}

Penelitian ini merupakan penelitian deskriptif, yaitu untuk mengetahui perilaku aktivitas olahraga mahasiswa kepelatihan olahraga selama bulan suci Ramadhan. Peneliti berusaha mengungkapkan fakta nyata yang terjadi di lapangan dan tidak bermaksud melakukan manipulasi data yang di peroleh. Partisipan dalam penelitian ini adalah mahasiswa program studi kepelatihan olahraga angkatan 2015. Data dikumpulkan dengan menggunakan kuesioner. Kuesioner yang disusun merupakan modifikasi dari Global Physical Activity Questionnaire (GPAQ). Melalui instrument ini, peneliti dapat mengetahui perilaku aktivitas fisik. Data yang terkumpul akan dianalisis secara deskriptif.

HASIL

Program Studi (Prodi) Pendidikan Kepelatihan Olahraga (PKO) Fakultas Keguruan dan Ilmu Pendidikan di Universitas Tanjungpura merupakan prodi baru. Prodi ini memiliki ijin operasional sejak tahun 2014, sehingga mulai tahun 2014 tersebutlah prodi PKO membuka pendaftaran jalur mandiri. Prodi PKO merupakan prodi yang bernaung di jurusan Ilmu Keolahragaan (Ikor). Jurusan Ikor sendiri menaungi dua prodi, yaitu prodi PKO dan prodi Pendidikan Jasmani, kesehatan dan rekreasi atau yang dikenal dengan penjaskesrek. Pembeda dari dua prodi ini adalah bahwa di prodi PKO mahasiswa wajib memiliki cabang olahraga yang akan digeluti.

Angkatan tahun 2015 merupakan angkatan kedua dari prodi PKO yang berjumlah 26 mahasiswa. Dari 26 mahasiswa tersebut terdiri dari beberapa cabang olahraga sebagai berikut:

Tabel 1. Distribusi Frekuensi Pilihan Kecabangan Olahraga

\begin{tabular}{clcc}
\hline No & & Kecabangan & Frekuensi \\
\hline $\mathbf{1 .}$ & Bola Voli & 6 \\
\hline $\mathbf{2 .}$ & Pencak Silat & 6 \\
\hline 3. & Tenis & 1 \\
\hline $\mathbf{4 .}$ & Sepak Bola & 6 \\
\hline $\mathbf{5 .}$ & Futsal & 3 \\
\hline $\mathbf{6 .}$ & Karate & 1 \\
\hline $\mathbf{7 .}$ & Tinju & 1 \\
\hline $\mathbf{8 .}$ & Renang & 2 \\
\hline
\end{tabular}

Terdapat 8 (delapan) cabang olahraga yng digeluti oleh mahasiswa prodi PKO. Dari masing-masing kecabangan olahraga tentunya memiliki jadwal latihan menyesuaikan dengan jadwal kuliah. Jadwal latihan dari berbegai cabang olahraga ini biasa dilakukan pada sore hari sekitar jam 15.30 - 17.30 WIB, kecuali pada cabang olahraga sepak bola yang memiliki jadwal latihan sore dan pagi hari terutama hari minggu.
Guna mendapatkan keterampilan teknik dasar dari kecabangan olahraga maka mau tidak mau mahasiswa harus tetap melakukan latihan secara rutin. Selain dapat memperbaiki teknik dasar maka latihan secara rutin juga akan meningkatkan skill yang dapat diperrgunakan dalam pertandingan.

Puncak dari latihan mahasiswa adalah pecan olahraga mahasiswa yang dilaksanakan di Makasar pada bulan Oktober 2017. Akan tetapi karena dalam 


\section{Jurnal Ilmu Keolahragaan Volume II Nomor 2 Oktober 2019 \\ Isti Dwi Puspitawati \\ Tersedia di: http://jurnal.untan.ac.id/index.php/jilo}

pecan olahraga mahasiswa tersebut Universitas Tanjungpura tidak mengirimkan banyak cabang maka tidak semua mahasiswa mencapai puncak performa yang harus ditampilkan. Cabang olahraga yang diberangkatkan pada pekan olahraga mahasiswa tersebut terdiri dari cabang olahraga karate, pencak silat, atletik dan catur. Oleh karena itu hanya cabang-cabang tersebutlah yang melakukan TC selama bulan puasa Ramadhan. Mahasiswa prodi PKO yang masuk dalam TC ada 6 orang mahasiswa yang terdiri dari 3 atlet dari kecabangan pencak silat, 2 atlet dari kecabangan karate dan 1 atlet dari kecabangan catur.

Atlet catur yang diberangkatkan merupakan mahasiswa angkatan 2017.
Sedangkan untuk cabang pencak silat dan karate merupakan mahasiswa angkatan 2015. Latihan yang dilakukan oleh atlet pencak silat dan karate dilakukan pada malam hari setelah solat tarawih sekitar jam 20.30 hingga jam 22.00 WIB. Training centre yang dilakukan tentu saja berdasarkan program latihan yang disusun dan dibuat oleh pelatih agar dapat memperoleh hasil sesuai target yang diinginkan. Berbeda dengan mahasiswa yang menjalani TC ini, sebagian besar mahasiswa yang tidak menjalani TC melakukan hal yang berbeda. Berikut data yang terkumpul dari hasil penelitian yang diperoleh .

Tabel 2. Distribusi Frekuensi Kegiatan Selama Bulan Ramadhan

\begin{tabular}{clc}
\hline No & Kegiatan/ Aktivitas & Frekuensi \\
\hline 1. & Latihan Sesuai Kecabangan & 3 \\
\hline 2. & Olahraga ringan pengisi hari & 7 \\
\hline 3. & Jalan-jalan menikmati sore & 10 \\
\hline 4. & Mengaji & 6 \\
\hline
\end{tabular}

Berdasarkan data diatas, rata-rata mahasiswa angkatan 2015 tidak melakukan aktivitas olahraga sesuai kecabangan. Mahasiswa lebih banyak membuang waktu dengan berjalan-jalan santai atau yang sering dikenal dengan "ngabuburit".

\section{PEMBAHASAN}

Di bulan Ramadhan, umat muslim yang berpuasa akan tidak hanya melakukan perubahan pola makan tetapi juga perubahan pola aktivitas. Perubahanperubahan itu diantaranya adalah perubahan jam makan, pembatasan waktu makan, dan perubahan pola tidur, hal-hal itu tentunya akan mengubah ritme keseharian seseorang secara drastis dan dapat memberi efek negatif terhadap performa fisik seseorang. Penurunan performa fisik saat berpuasa umumnya dikaitkan dengan dehidrasi, keterbatasan asupan nutrisi, kurangnya istirahat, perubahan mood, dan perasaan lemas.

Melakukan aktivitas fisik tambahan atau berolahraga pada saat berpuasa tentu akan memberi tambahan stressor pada tubuh. Melakukan olahraga dengan pola yang sama seperti sebelumnya tanpa memperhitungkan pengaruh puasa pada tubuh justru akan dapat berpengaruh buruk terhadap kesehatan. Cara yang paling sederhana untuk mengurangi dampak puasa pada saat seseorang berolahraga di bulan Ramadhan adalah dengan memodifikasi program olahraga sesuai dengan pola aktivitas saat berpuasa.

Pada saat berpuasa, umat muslim akan mulai berpuasa saat sahur pada pukul 04.30-05.00 hingga saat matahari terbenam pada pukul 17.30-18.00. Apabila waktu latihan tidak disesuaikan dengan waktu pembatasan asupan makanan dan cairan selama berpuasa, 


\section{Jurnal Ilmu Keolahragaan Volume II Nomor 2 Oktober 2019 \\ Isti Dwi Puspitawati \\ Tersedia di: http://jurnal.untan.ac.id/index.php/jilo}

maka latihan yang dilakukan bisa jadi tidak membuat tubuh lebih sehat tetapi justru dapat memberikan gangguan kesehatan. Waktu latihan adalah aspek yang penting untuk dimodifikasi pada saat berpuasa. Rekomendasi waktu latihan saat berpuasa adalah setelah sahur, sebelum berbuka puasa dan setelah berbuka puasa Berdasarkan kebiasaan berolahraga, dapat dibagi menjadi tiga macam, yaitu yang tak pernah berolahraga, rutin berolahraga, dan atlet. Bagi orang yang tidak pernah berolahraga, pada saat puasa, disarankan memulai olahraga sekitar 30 menit sebelum berbuka. Sedangkan bagi yang bermasalah dengan penyakit (misal diabetes, sakit jantung, stroke) dan ingin olahraga untuk hidup sehat, harus melakukan konsultasi terlebih dahulu dengan dokter. Bagi yang sudahh terbiasa berolahraga, bisa disesuaikan dengan tujuan. Bila ingin menggurangi lemak, maka 45 menit - 1 jam sebelum buka adalah waktu terbaik dengan olahraga intensitas tinggi. Sedangkan bagi atlet atau yang senang olahraga keras, waktu terbaik untuk mulai adalah sekitar pukul 20.30 atau dua jam usai makan. Bila buka puasa pukul 18.00 dan makan pukul 18.30, maka waktu 2 jam sudah cukup untuk perut diajak olahraga. Tubuh sudah mulai mengosongkan isinya.

Sebelum berolahraga harus memastikan sudah memasukan cairan sekitar 2 liter mulai dari buka sampai dengan mulai olahraga dahullu. Karena tubuh berada dalam status dehidrasi setelah 14 jam puasa. Jaga durasi maksimal olahraga 1,5 jam. Supaya tubuh tidak mengalami overtraining. Dan tetap menjaga hidrasi minimal minum 1 liter air sampai waktu tidur masuk ke dalam tubuh.

Namun hal ini tidak dilakukan oleh mahasiswa Prodi PKO yang nota bene merupakan atlet dan pelatih diberbagai cabang olahraga. Rerata dari mahasiswa di program studi PKO justru meliburkan diri dari kegiatan aktivitas berolahraga. Meskipun mahasiswa tersebut mengetahui dampak negative dari berhentinya secara mendadak aktivitas olahraga yang telah dilakukan selama ini. Dampak negative dari non aktif aktivitas olahraga tidak membuat ciut nyali para mahasiswa untuk menikmati waktu liburan bersama dengan keluarga.

Hanya terdapat 3 mahasiswi yang masih tetap berlanjut melakukan aktivitas olahraga. Hal ini dikarenakan ketiga mahasiswi tersebut masuk dalam training centre (TC) karena akan mengikuti pecan olahraga mahasiswa pada bulan oktober 2017. Ketiga mahasiswa tersebut dari cabang pencak silat dan karate. Dari cabang pencak silat melaksanakan latihan pada malam hari selama 2, 5 jam per hari. Berbeda dengan cabang karate, yang melaksanakan latihan pada sore hari selama kurang lebih 2 jam perhari.

Aktivitas selama bulan puasa Ramadhan memang memaksa pemeluknya untuk merubah pola aktivitasnya. Seperti makan dan minum, jelas sekali bahwa pada siang hari pemeluk agama islam tidak diperkenankan untuk melakukannya. Sehingga aktivitas olahraga terpaksa dirubah jam pelaksanaan oleh para atlet ataupun penggiat olahraga. Hal ini disebabkan karena ketakutan agar tidak terjadi dehidrasi akut yang dapat menyebabkan orang yang melakukan puasa tidak kuat menjalankan ibadah puasa.

Aktivitas olahraga yang semula dilakukan setiap sore haripun segera dirubah dan atau ditinggalkan. Hal ini disebabkan karena pada saat bulan Ramadhan ini intensitas kegiatan keagamaan lebih banyak, seperti mengaji di sore hari sebelum buka puasa, solat tarawih setelah selesai solat isya dan bahkan khataman membaca alquran setelah tarawih.

Intensitas kegiatan keagaamaan
yang reltif tinggi tersebutlah kemungkinan yang membuat para mahasiswa prodi PKO angkatan 2015 ini 


\section{Jurnal Ilmu Keolahragaan Volume II Nomor 2 Oktober 2019 \\ Isti Dwi Puspitawati \\ Tersedia di: http://jurnal.untan.ac.id/index.php/jilo}

tidak melakukan latihan sesuai kecabangan yang diambilnya. Terlebih pada saat bulan Ramadhan mahasiswa telah selesai ujian akhir, hal ini menambah alasan yang kuat bagi para mahasiswa untuk tidak melakukan latihan sesuai kecabangannya secara rutin dan kontinu.

\section{KESIMPULAN}

Di bulan Ramadhan, umat muslim yang berpuasa akan tidak hanya melakukan perubahan pola makan tetapi juga perubahan pola aktivitas. Perubahan-perubahan itu diantaranya adalah perubahan jam makan, pembatasan waktu makan, dan perubahan pola tidur, hal-hal itu tentunya akan mengubah ritme keseharian seseorang secara drastis dan dapat memberi efek negatif terhadap performa fisik seseorang.

Perubahan pola aktivitas juga dialami oleh mahasiswa prodi PKO angkatan 2015 yang semula setiap sore hari sekitar jam 15.30 hingga jam 17.30 melakukan aktivitas latihan rutin sesuai kecabangan olahraga yang diambil, pada bulan Ramadhan ini mahasiswa tidak melakukan latihan sesuai kecabangannya. Justru kegiatan "ngabuburit" yang lebih banyak dilakukan oleh mahasiswa. Dari 26 mahasiswa di angkatan 2015 hanya 3 mahasiswa yang terus melakukan latihan sesuai kecabangan itupun karena 3 mahasiswa tersebut masuk dalam TC karena masuk dalam tim Pekan olahraga mahasiswa di Makasar Bulan Oktober 2017.

Sebagai orang yang berkecimpung dalam dunia olahaga, seharusnya tetap melakuan aktivitas olahraga minimal untuk menjaga kebugaran jasmani. Aktivitas jasmani pada saat bulan Ramadhan dapat dilakukan meskipun ada perubahan pada jam, yaitu pada waktu mendekati buka puasa.

\section{DAFTAR PUSTAKA}

Chaouachi, A, Leiper, J.B, Chtourou, H, Aziz, Abdul R \& Chamari, Karim.(2012). The effects of Ramadan intermittent fasting on athletic performance: Recommendations for the maintenance of physical fitness. Journal of Sports Sciences Volume 30, 2012 - Issue sup1. http://www.tandfonline.com/doi/fu 11/10.1080/02640414.2012.698297 ?scroll=top\&need Access=true. Akses 11 Mei 2017.

Erlangga, M. (2014). Riset aCommerce Temukan Perubahan Pola Perilaku Pebelanja Online Selama Bulan Ramadhan.

https://dailysocial.id/post/risetacommerce-temukan-perubahanpola-perilaku-pebelanja-onlineselama-bulan-ramadhan. Akses 11 Mei 2017.

Jasem Ramadan Alkandari, Ronald J. Maughan , Rachida Roky , Abdul Rashid Aziz \& Umid Karli . (2012). The implications of Ramadan fasting for human health and wellbeing. Journal of Sports Sciences Volume 30, 2012 - Issue sup1. Akses 11 Mei 2017

Kirkendall DT, Leiper JB, Bartagi Z, Dvorak J, Zerguini Y. (2008). The influence of Ramadan on physical performance measures in young Muslim footballers. J Sports Sci. 2008 Dec;26 Suppl 3:S15-27. Akses 11 Mei 2017

Kirkendall, D, Anis Chaouachi , Abdul Rashid Aziz \& Karim Chamari . (2012). Strategies for maintaining fitness and performance during Ramadan. Journal of Sports Sciences Volume 30, 2012 - Issue sup1. Akses 11 Mei 2017.

Kaarud,E.A., Hashim, H. A. and S. Saha. (2016). The Effects of a Single 


\section{Jurnal Ilmu Keolahragaan Volume II Nomor 2 Oktober 2019 \\ Isti Dwi Puspitawati \\ Tersedia di: http://jurnal.untan.ac.id/index.php/jilo}

Bout of Moderate Cycling Exercise During Ramadhan Fasting on Mood States, Short-Term Memory, Sustained Attention and Perceived Exertion among Sedentary University Students. Pertanika J. Soc. Sci. \& Hum. 24 (4): 1601 1610 (2016).

R.J. Maughan \& S.M. Shirreffs . (2012). Ramadan fasting and the goals of sports nutrition around exercise. Journal of Sports Sciences Volume 30, 2012 - Issue sup1. Akses $11 \mathrm{Mei}$ 2017.

Ronald J. Maughan , Yacine Zerguini, Hakim Chalabi \& Jiri Dvorak. (2012). Achieving optimum sports performance during Ramadan: Some practical recommendations. Journal of Sports Sciences Volume 30, 2012 - Issue sup1. Akses $11 \mathrm{Mei}$ 2017.

WHO. Global Physical Activity Questionnaire.

http://www.who.int/chp/steps/reso urces/GPAQ_Analysis_Guide.pdf. Akses 11 Mei 2017 